\title{
The legal sustainability of energy substitution in Nigeria's electric power sector: renewable energy as alternative
}

\author{
Olusola Joshua Olujobi
}

\begin{abstract}
Non-renewable fuel sources have been the predominant energy sources and a significant source of foreign exchange income for Nigeria, while at the same time there is a severe problem of electricity inconsistency and persistent power blackouts in Nigeria. The research aims to end the concern for deficient energy use, and to encourage energy efficiency and sustainability. Nigeria has not maximized the advantages of renewable energy after the denationalisation of its electricity industry despite the current transformation in the power industry and the rising demand for renewable energy supply. The research adopts a doctrinal legal approach with a library-based legal research technique with a comparative legal method. It reveals that the absence of a comprehensible legal regime with encouragement for the use of renewable energy is the fundamental element causing the slow utilization of renewable energy as a substitute source of energy in Nigeria. It is suggested that, among other reforms, there is a need for a comprehensible legal regime on renewable energy and the encouragement of strict implementation of energy regulatory strategies and policies with incentives for the application of renewable energy sources in Nigeria.
\end{abstract}

Keywords: Non-renewable energy, Sustainability, Renewable energy, Fossil fuel, Nigeria

\section{Introduction}

Non-renewable fuel has been the primary source of power supply, and since non-renewable fuel discharges greenhouse gases it has become untenable generally [1]. The ecosystem is under threat from crude oil exploration, production and the use of oil, and there is continued global warming and exhaustion of the ozone layer amplified by the discharged greenhouse gases.

Humans, vegetation and animals have also been adversely affected owing to ecological deterioration and dilapidation from the occurrence of oil exploration in the Niger Delta Areas of Nigeria [2]. Therefore, there is a need for a new energy policy that will encourage renewable energy usage in Nigeria, and the power sector outside denationalization needs energetic and regulatory

Correspondence: olusola.olujobi@covenantuniversity.edu.ng

Legal Practitioner and Lecturer, Business Management Department Covenant University Ota Ogun State Nigeria reformation for maintainable, ecological and public responsive energy laws in Nigeria. There are large capacities of renewable energy sources in the country's tropics, with its landmass widening amid latitudes 5 degrees south and 15 degrees north of the equator. Nigeria receives a large amount of sunlight [3] particularly in the north where the sunlight can produce approximately 1850 X 103 Gigawatt hours per year (GWh/yr) of solar power. This exceeds the present grid of energy consumption in the country [4]. Biomass is another renewable, low carbon fuel that is widely accessible throughout the country and it could ensure continuous energy supply to rural areas. However, there is no comprehensible legal regime on renewable energy up till now in the country. Conversely, the government has an enormous reserve of natural resources for alternative energy making such as productive cultivable fertile land, supportive climatic environments in feedstock 


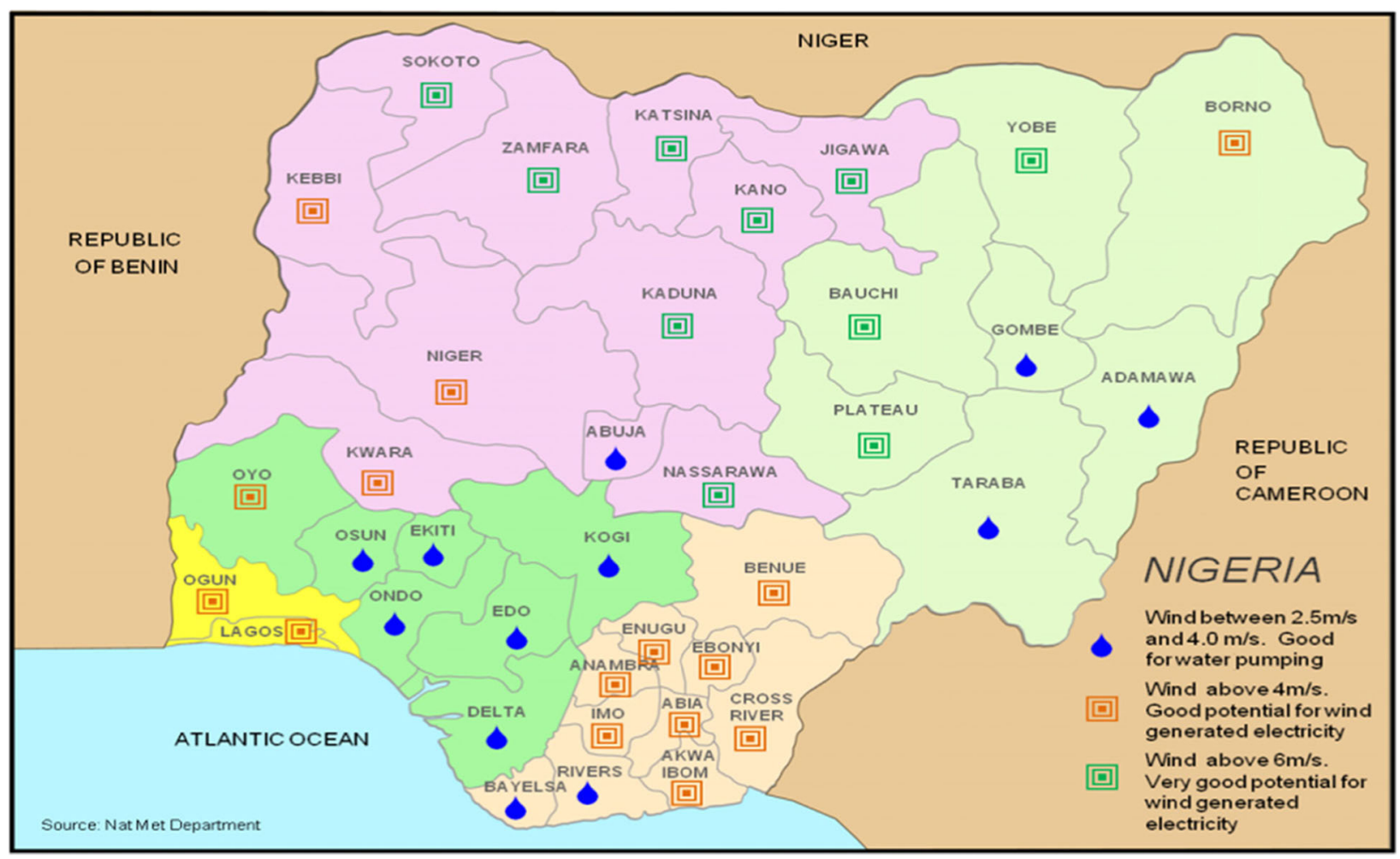

Fig. 1 Map of Nigeria Showing Geographic Allotment of Nigeria's [11]

fabrication, for instance, cassava, maize, sugarcane, palm oil, among others (Fig. 1).

Energy strategy or policy is the disposition of action or declaration of principles planned or accepted by the government to ensure the accessibility of fuel and other substitute resources used for managing machinery. A novel energy policy or strategy permits many governments to deviate from the utilisation of coal, oil and natural gas to embrace substitute renewable energy resources including geothermal, biofuels, biomass, solar, wind, and hydropower. They are acquired from non-fossil and non-nuclear resources in methods

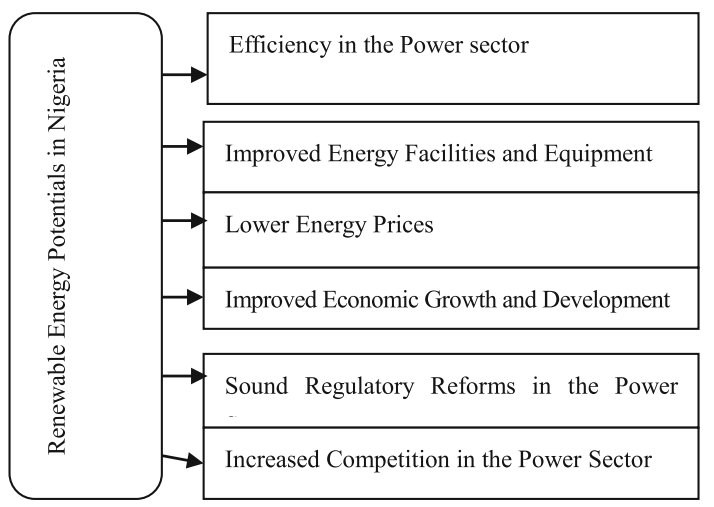

Fig. 2 Advantages of Renewable Energy in Nigeria that can be replenished, and are environmentally responsive [5] (Fig. 2).

This novel energy strategy is a phenomenon, and is the panacea to one of the utmost arduous difficulties facing the world presently by producing energy or power devoid of fast-tracking climate change, harming the ecosystem or damaging food production. Jurgen Tritten, Germany's past Federal Environmental Minister said that the use and growth of renewable energies is a state where all interested parties will gain in one way or another including both the developed and developing nations. Renewable energy conserves the ecosystem, eliminates deprivation, and encourages

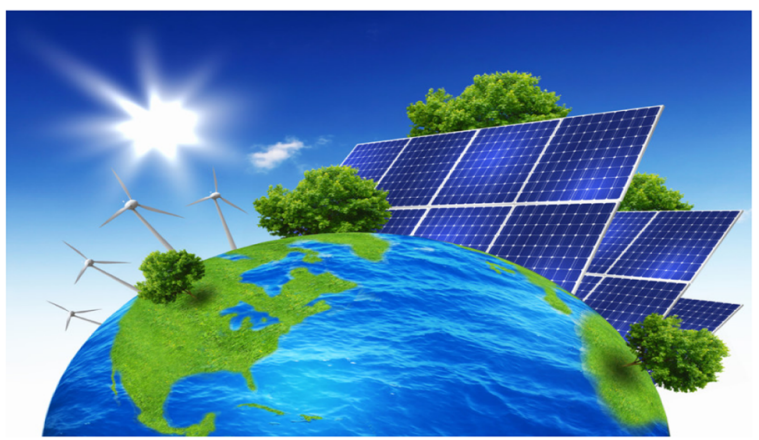

Fig. 3 Renewable Energy Sources [42] 
Table 1 Power Plants in Nigeria Using Renewable Energy Sources but not at Maximum [34]

\begin{tabular}{|c|c|c|c|c|c|c|}
\hline $\mathrm{S} / \mathrm{N}$ & $\begin{array}{l}\text { Power } \\
\text { Plants }\end{array}$ & $\begin{array}{l}\text { Energy } \\
\text { Sources }\end{array}$ & Category & Capacity & Situation & $\begin{array}{l}\text { Date of } \\
\text { Completion }\end{array}$ \\
\hline 1. & $\begin{array}{l}\text { Mambilla } \\
\text { Power } \\
\text { Station }\end{array}$ & $\begin{array}{l}\text { Hydro } \\
\text { electric }\end{array}$ & Reservoir & $3050 \mathrm{MW}$ & $\begin{array}{l}\text { Functioning } \\
\text { but not } \\
\text { optimally }\end{array}$ & 2018 \\
\hline 2. & $\begin{array}{l}\text { Kiri } \\
\text { Power } \\
\text { Station }\end{array}$ & Hydroelectric & Reservoir & $100 \mathrm{MW}$ & $\begin{array}{l}\text { Functioning } \\
\text { but not } \\
\text { optimally }\end{array}$ & 2016 \\
\hline 3. & $\begin{array}{l}\text { Zamfara } \\
\text { Power } \\
\text { Station }\end{array}$ & Hydroelectric & Reservoir & $35 \mathrm{MW}$ & $\begin{array}{l}\text { Functioning } \\
\text { but not } \\
\text { optimally }\end{array}$ & 2015 \\
\hline 4. & $\begin{array}{l}\text { Kano } \\
\text { Power } \\
\text { Station }\end{array}$ & Hydroelectric & Reservoir & $100 \mathrm{MW}$ & $\begin{array}{l}\text { Work in } \\
\text { progress }\end{array}$ & 2015 \\
\hline 5. & $\begin{array}{l}\text { Shiroro } \\
\text { Power } \\
\text { Station }\end{array}$ & Hydroelectric & Reservoir & $600 \mathrm{MW}$ & $\begin{array}{l}\text { Work in } \\
\text { progress }\end{array}$ & 1990 \\
\hline 6. & $\begin{array}{l}\text { Jebba } \\
\text { Power } \\
\text { Station }\end{array}$ & Hydroelectric & Reservoir & $540 \mathrm{MW}$ & $\begin{array}{l}\text { Work in } \\
\text { progress }\end{array}$ & 1985 \\
\hline 7. & $\begin{array}{l}\text { Kainji } \\
\text { Power } \\
\text { Station }\end{array}$ & Hydroelectric & Reservoir & $800 \mathrm{MW}$ & $\begin{array}{l}\text { Work in } \\
\text { progress }\end{array}$ & 1968 \\
\hline
\end{tabular}

novel technologies and initiates new job opportunities in the energy industry [5] (Fig. 3).

Similarly, the use of renewable energy complies with the World Summit on Sustainable Development resolutions organised in Johannesburg, South Africa in 2002 where over 30 countries stated their responsibilities in enhancing renewable energy source use and in setting up their energy synopsis in achieving this aim [6].

Consequently, numerous nations, including Israel, China, Germany, Chile, Spain and Denmark among others have all embarked on a paradigm shift to a new energy policy on renewable energy. For instance, Brazil has exhibited an absolute obligation to the development of renewable energy via legislation on a modern hydropower rule and strategy, the Biodiesel Rule and the Ethanol Rule [7]. The novel energy rule envisioned by the past US President, Barack Obama, attempted to use additional alternate energy sources which are considered to be inexpensive and more ecologically responsive than crude oil and its associated commodities [8]. Thus, the United States via the "Novel Energy Economy" attempted to get the populace to reflect on clean energy financing, increasing fuel efficiency in cars and decreasing greenhouse gas emissions by getting to the point where at least $25 \%$ of the country's energy derives from renewable sources [9].

The United Kingdom in 1990-2004 increased renewable energy production by 12 -fold. Kenya produced approximately $923 \mathrm{MW}$ geothermal, wind and solar energy for electricity in 2010, while the 2012 Kenyan Energy Rules require the compulsory installation of solar water heaters in all houses, particularly where there is an excess of $100 \mathrm{l}$ of water usage per day. Effective incorporation of renewable energy into these nations' energy systems is achieved through strict and comprehensible implementation of their energy laws [9].

The International Energy Agency presented two instances in its world energy perspective on how strategies can influence the international energy market, energy securities and other energy-interrelated anxieties. Primarily, a question is in what manner will international energy markets improve the lack of ingenious administrative policies on the energy industry and international energy markets if they are devoid of inventive administrative rules on energy growth and use.

Renewable energy is a unique aspect of the devolved energy industry in the country and to enhance the advantages of renewable energy in Nigeria, it needs appropriate planning with a robust legal framework on renewable energy to encourage investment in the industry [10].

The trajectory and growth of electricity laws in Nigeria have actually been degenerating rather than improving as regards the efficacy of a regulatory and institutional legal regime that will enhance efficient management of electricity in the country. The obsolete National Electric Power Authority's responsibilities on generation, transmission and allocation of electricity in Nigeria have been poor, erratic and defective -- a plethora of legal regimes and strategies legislated upon in fact appeared were incapable of resolving the problems in the power sector. With the contemporary legal regime under the Electric Power Sector Reform Act 2005, the Power Holding Company of Nigeria (PHCN) was divided into 18 firms as part of the transformation activities of the industry but it has not proven to improve electricity supply in the country. Thus, it is necessary for renewable energy to supplement the current sources of energy in Nigeria's power industry.

This paper focuses on a synopsis of the novel energy policy, followed by various alternative renewable energy sources. The benefits of renewable energy are summarized and the new energy strategy or policy in Nigeria is considered. The consequences of the novel energy policy for the petroleum industry in Nigeria are analyzed with a succinct comparative assessment of the legal regime on renewable energy in some designated nations. Finally, it draws a conclusion and proffers suggestions for energy security and sustainability in the country.

\section{Literature review}

Numerous scholars have written on the necessity for renewable energy sources in Nigeria from the legal viewpoint, but no one has contemplated the capabilities and the effects of renewable energy in the nation and the need for stringent compliance with the novel energy strategy or policy [12] deemed laws on renewable energy 
as inevitable for Nigeria's growth and for the sustainability of Nigeria's energy industry. On the contrasts between renewable energy and conventional energy resources, [13] look at the consideration of the government's statutory agencies on the intricate characteristics of petroleum resources ownership and control in the country. These are exclusively conferred on the Federal Government and this has hampered adequate financing on electricity provision to the rural inhabitants. There is a need for all governments at all levels to be permitted to partake in electricity generation and distribution via the alteration of the existing energy laws and policies. However, the function of renewable energy and its social, commercial and ecological impacts have not been comprehensively reviewed by these analyses. Numerous researchers valued the significance of renewable energy, but the studies failed to design a model law appropriate for tackling Nigeria's unique electricity problems.

The work by [14], in "Essay on Nigerian Electricity Law" considers that the fundamental challenge with the statutory and governance framework in the country is the over concentration of the management and organisational structure of the power industry. A decentralized structure has assisted numerous nations to tackle the electricity problem via off-grid renewable electricity generation, transmission and distribution for speedy rural electrification for social and economic growth.

Similarly, according to Oniemola [14] the advantages of renewable energy are more than its ecological impact. The current research considers that there is a need for model legislation with an incentive for the use of renewable energy as a substitute source of energy to promote investment in the industry. Similarly, Mallom [15] pinpoints the need for comprehensive policy growth and execution on renewable energy to encourage energy security and efficiency, while in Oyedepo 2012 [16] it states that energy security is the cornerstone upon which every advanced economy is planned. However, the current research submits that affordability is the primary concern owing to the persistent energy insecurity and inefficiency tolerated by energy consumers in Nigeria, given the high tariff handed down via estimated billings. Thus, it is necessary to strictly control the instrument of laws to combat corruption and exploitation in the industry [17].

\section{Statement of research problems}

Currently, the Federal Government of Nigeria has no comprehensive laws on renewable energy, while strategies and policies on energy are dispersed and incoherent within the legal framework. The demand for electricity outweighs supply, and this has affected social and economic development in the country in the areas of impecuniousness mitigation, commercial output, electricity customer well-being, human health via smoke inhalation from domestic cooking and the usage of local electricity generator sets to produce power. If this challenge is tackled, it will have the capacity to lessen climate change consequences and to safeguard Nigeria's petroleum resources for sustainability [5].

Numerous nations, for instance, Germany, India and China etc. are the trailblazers in renewable energy growth and utilization, with proper legislation. In contrast, the Federal Government of Nigeria is yet to legislate a comprehensive law on renewable energy, while the predominant rules on renewable energy are dispersed in numerous policies and strategies which are incoherent and ambiguous in scope [18].

Furthermore, the inefficient and inconsistent power supply configuration in Nigeria has led to losses of over $30 \%$ of the total energy generated. In addition to these shortcomings, the stability and availability of the installed energy production system are low. There is a critical problem of power inconsistency over the years that has led many firms and wealthy families to install expensive electricity generators that cost over half of the total installed grid capacity, which constitutes an enormous economic deficit to the Nigerian economy. The fundamental elements triggering irregularity and inefficiency in the power sector are a persistent breakdown of generating plants and equipment due to inadequate and insufficient repairs and absence of foreign exchange to acquire the required spare parts promptly, outdated transmission and distribution equipment, shortage of a competent energy workforce, and deficiency of essential firms to service the industry.

Other severe anxieties include low or deficient energy financing, deteriorating technical knowledge in the power industry and an ineffective statutory framework. The power industry is a substantial beneficiary of the domestic budget, swallowing large financial resources, a large workforce and continuous foreign exchange discharges, but there is lacking an obligatory, enforceable legal or regulatory framework that governs renewable energy use for domestic development and socioeconomic growth in the country [19].

Rural inhabitants in Nigeria depend on crude energy systems for such as indoor cooking which may pose a severe threat to human health via smoke inhalation. This has triggered many deaths which could be avoided through stringent and coherent laws on renewable energy to promote energy security, efficacy and sustainability [20].

Renewable energies are used at a meagre ratio in Nigeria while fossil fuels remain the main sources of energy. Therefore, there is a need for intensive investment in the power industry to make renewable energy a substantial substitute source of commercial energy in Nigeria [21]. 


\section{Theoretical framework on renewable energy in Nigeria}

Resource Curse Theory was formulated around 1970-1990, and emphasizes that emerging nations must protect the promotion and growth of renewable energy sources via comprehensive laws to safeguard and highlight social, financial and ecological interests of the present need in addition to sustaining the same for upcoming generations. Emerging nations must guarantee that their extractive resources do not encourage underdevelopment and other economic crises related to resource-rich states, for instance, poverty and poor social infrastructure. The theory helps research by underlining the need to safeguard and protect the state's extractive resources for posterity. It also focuses on the need to boost the social and economic development of Nigeria via the rich petroleum resources for energy sustainability and to the advantage of the inhabitants [22].

The model will assist in mitigating the consequences of climate change through the consistent implementation of the extant laws on energy in all emerging petroleum exporting countries. It highlights that those resource-rich nations are mostly undergoing low economic growth. The theory further emphasizes that resource-rich countries lack economic prosperity and development that are proportionate with their rich petroleum resources owing to prevalent violence, corruption [17], failure to diversify their economies and natural resources to other natural endowments such as agriculture, solid minerals etc. Therefore, there is need for strict enforcement of its existing laws on transparency in the extractive industries and other environmental laws to protect social, economic and other ecological interests in the industry [23].

Another pertinent theory adopted in this research is the 1980 sustainable development theory which was devised at the Stockholm Conference on Human Environment in 1972. It states that governments should use their extractive resources in a sustainable model for growth that satisfies the existing needs without compromising capacity and the needs of future generations. The theory assists studying to comprehend the need for efficient use of extractive resources, the strategy of financing, the thrust of technological innovation, and the legal framework in agreement with international best practice for the sustainability of humankind and nature. The theory underlines the need to utilise natural resources for the value and advantages of the present-day generations and upcoming generations without any detrimental effects on the ecosystem. Consequently, it is necessary to accept renewable energy as alternative sources of energy in Nigeria's power industry to tackle the problem of power supply in the country. Nigerian policy-makers must strive for fair and balanced strategies and policies to ensure energy security in the industry for the common good of Nigerians [2].

\section{Legal framework and statutory institutions regulating renewable energy in Nigeria}

The 1999 Constitution of the Federal Republic of Nigeria (as amended) places electricity on the concurrent legislative list. This authorizes all levels of governments to take part in significant phases of electricity distribution and allocation in the country, as stated in Paragraph 14 of Schedule II of the same Constitution.

Moreover, the Electric Power Sector Reform (EPSR) Act 2005 underlines the meaning of renewable electricity in the international energy mix to ensure access to electricity in rural and remote areas. The National Energy Policy of August 2003 stresses the total thrust of energy policy by safeguarding the best method for the utilisation of Nigeria's energy resources for sustainable development of its energy industry. There are other energy policies such as the 2009 Draft Renewable Electricity Policy, the 2000 Renewable Action Plan and Renewable Energy Master Plan 2012, which encompass plans for renewable energy in Nigeria's economy. Also, the National Energy Policy 2013 and the Draft National Energy Master Plan (NEMP) 2014 created the National Renewable Energy Development Agency with the statutory responsibility of making renewable energy a significant source of green energy in Nigeria.

An additional regulatory institution in the industry is the Federal Ministry of Power and Steel, which has the following related statutory tasks: the power to recommend policy and to make recommendations to the Federal Government of Nigeria on laws, strategies and financing on renewable energy. It is authorized to monitor and appraise the application and performance of the policy within governmental agencies and in the electricity markets. To evaluate the performance of renewable electricity policy through increased access to electricity in rural areas in Nigeria is fundamental to boost the economy [24].

According to the new energy policy, the Federal Government through the Nigerian National Petroleum Corporation (NNPC) inaugurated a Renewable Energy Division in NNPC to develop a renewable energy initiative in August 2005 with the tasks of harnessing biofuel in Nigeria for the satisfaction of energy customers. However, the division has not been efficient in carrying out this task [6]. Later, Nigeria approved a policy on biofuels called Nigeria Bio-Fuel Policy and Incentives 2007. The strategy was ratified by the Federal Executive Council on June 20, 2007 and became a National Bio-Fuels Policy. Under the policy, NNPC was to create an enabling environment for the commencement of a domestic ethanol fuel industry. Subsequently, Africa's first ethanol refinery was introduced in Ekiti State and Ondo State in 2009 [25]. The aims were to reduce Nigeria's over-dependence on imported gasoline and to create a commercially sustainable energy industry that can employ the country's youth. 
However, the development in Nigeria's energy sector is slow because of inefficiency in the industry [26].

However, over US $\$ 4$ billion has been earmarked for a sugarcane-sourced ethanol project in Jigawa and Benue States, while cassava-sourced ethanol projects are to be established in Anambra and Ondo States. Also, the Biofuels Research Agency is to coordinate biofuel research in Nigeria and to work with the Ministry of Agriculture, Ministry of Science and Technology on crop production but the Ministries have not been proactive in driving this project because of lack of funds and the requisite technical know-how on renewable energy [27].

The Ministry of Science and Technology is to preserve records of all biofuel projects, to issue licenses to operators for the development of fuel ethanol or biodiesel in the country, and to enact and endorse financial and other incentives for the industry. It is a simple fact that renewable energy will boost Nigeria's electric power industry since current electricity supply satisfies only onethird of the energy needs. It will also preserve nonrenewable energy sources, for instance, Nigeria's 36.5 billion barrels of crude oil reserves by shifting Nigeria's focus from crude oil to renewable energy thereby ensuring a clean, inexhaustible energy supply, protecting the human and natural environment for socio-economic development that will guarantee sustainable energy security in Nigeria [28].

The Nigerian Electricity Regulatory Commission (NERC) was instituted by the Electric Power Sector Reform (EPSR) Act 2005 to initiate, promote, and preserve efficient energy market structures for optimal utilisation of energy resources for electricity services. The commission is to improve access to energy services by boosting and empowering consumer connections to distribution systems in both countryside and city areas and to guarantee a stable supply of electricity to consumers. However, the commission has not been efficient in this regard as several communities in Nigeria have not had constant power supply, and some have not been connected to the national grid for electricity supply. Another institution is the Rural Electrification Agency established by the EPSR Act 2005 to extend the primary grid, to develop isolated, mini-grid systems and renewable energy for power generation. Also, the Energy Commission of Nigeria was inaugurated to conduct strategic planning and to harmonize domestic policies on energy. Other Agencies from which to seek advice in the execution of this rule are the Federal Government institutions, State Rural Electrification Boards and some relevant state agencies, organised private sector and Non-Governmental Organisations which are participants in the projects [24].

Another law regulating the industry is the Nigerian Oil and Gas Industry Content Development Act, whose objective is to strengthen home-grown participation or to build local capacities in the Nigerian oil and gas industry. One of its regulatory tasks is to set the standards for local content, though it was not specifically outlined under the Act. Sections 102 and 11(4) of the Act providing for the appraisal of the schedule to the Act every two years and the waiver clau cxzse every three years after the enactment of the Act. However, these have not been done to promote economic growth in the sector and to combat other uncertainties connected with the industry [29].

The proposed Petroleum Industry Governance Bill (PIGB) 2017 emphasises governance issues in Nigeria's oil and gas sector by separating the roles of the Nigerian National Petroleum Corporation (NNPC) in operating as a regulator as well as an operator. While unbundling the corporation to two different limited liability firms, the purpose is to remove the discretionary power of the Minister of Petroleum to award oil licences or leases, but such authority can only be exercised now based on the authorisation of the new commission called the Petroleum Regulatory Commission, which is the planned statutory body for the oil and gas industry. Expeditious passage of the bill into law by the current 9th National Assembly will encourage the desired reforms in the industry in the areas of good governance, licensing, fiscal policy, restructuring of the corporation as a commercial legal entity to combat legal, regulatory challenges on gas utilisation, market, pricing and growth in Nigeria and Africa.

\section{Results and discussion of findings}

The review underlines the significance of renewable energy to sustainable electricity in Nigeria with emphasis on the legal and policy framework that needs to be enacted to promote energy sufficiency and security via renewable energy. Nigeria's law for the utilisation and growth of renewable energy is not detailed and not adequate to meet the social, economic and environmental development needs of the country. The existing policies on renewable energy are dispersed in numerous policy documents which are incoherent and narrow in scope. Thus, the Federal Government must do more to overcome all the challenges associated with the formulation of a coherent legal regime on renewable energy to guarantee energy efficiency, security and sustainability in Nigeria. In addition, the ineffective and erratic power supply structure in Nigeria has caused losses of more than $30 \%$ of the total energy produced, while there is very low consistency and accessibility of currently installed electricity production. Consequently, the severe problem of low power reliability has led many industrial organizations and upper-income families to install their own electricity generator sets that cost over half of the total installed grid capacity, constituting colossal economic deficits to the Nigerian economy. Therefore, there 
is a need for stringent enforcement of energy regulatory policies with incentives for utilisation of renewable energy sources for rapid growth in the industry [30].

\subsection{Renewable energy as investment prospects for Nigerians}

There are several new renewable energy prospects accessible in Nigeria. Biomass is a green energy source derived from plants. It can be utilised as bio-power or transformed into other energy commodities such as biofuel, and can reduce greenhouse gas emission. It is the cheapest and most accessible source of energy, and can be derived from agitated ethanol and distillation of starchy cereals, grains and sugar crops such as beet, wheat, corn, sorghum and sugarcane [31]. This is a prospect which can produce good profits for Nigerians through investment in biofuel products (Table 1).

Biogas is another source of energy that is obtained from unprocessed and discarded materials such as animal feces, and decomposable manufacturing and domestic unwanted solid materials [5]. Biodiesel is produced by converting oil-bearing crops such as coconut, soya, palm, rapeseed and sunflower to methyl esters to blend with conventional diesel. Biomass as a renewable energy source can promote constant power supply to rural areas through a rural electrification programme and improve the livelihood of the rural dwellers. However, despite its comparative benefits and abundance in Nigeria, there is no legislation on biomass as a source of renewable energy. Thus, there is an urgent need for legal and policy framework on biomass in Nigeria [32].

Wind energy is another source of renewable energy that can promote a stable electricity supply in Nigeria to meet the needs of its electricity consumers primarily in the northern part of the country where there is abundant wind energy at 4.0 to $5.12 \mathrm{~m} / \mathrm{s}$ speed [33]. Wind energy is categorised as a highly ecologically responsible resource of renewable energy. It involves the installation of wind turbines in a wind farm located in an area where winds are durable and persistent, for instance, in offshore and high-altitude locations [33].

Another source of energy that is cheap and efficient to maintain is small hydropower. There are many forms of water energy such as hydroelectric energy, micro-hydro systems, dam less hydro, oceanic energy, etc. The systems harness water to generate energy through technologies such as dams, tidal power, and marine current power, among others [5].

Solar energy is obtained from the sun through solar activity or radiation such as photovoltaic and heat. Other sources of solar energy include space heating and cooling through solar design, daylighting, and solar hot water, solar steaming and high-temperature practices for commercial energy usage [14]. Solar energy is widely available in Nigeria because of abundant sunshine, but the technology has not been fully accepted by all households in the country despite efforts to create awareness of its use and efficiency. This is a source of renewable energy that is cost-effective and can stimulate regular power supply and sustainable development in the rural areas [32].

\subsection{The advantages of renewable energy in Nigeria}

There has been a strong new interest in renewable energy sources because of their advantages over fossil fuel. The elements inspiring the growing interest in renewable energy include the following:

- Renewable energy improves energy security because of crude oil theft and pipeline vandalism, reduction of oil reserves and the increasing cost of crude oil exploration. All these point to the fact that fossil fuel may not guarantee all-time availability of energy for human use. A diversified energy programme would mitigate the potential problem of energy insecurity and sustainability in Nigeria [35].

- The cost of extracting, tapping and harnessing energy from renewable sources is relatively low in the long term compared to that of fossil fuel. Consequently, the supply of alternative energy is cheaper than that of fossil fuel.

- Environmental pollution and degradation, as well as global warming, are incidental to the exploitation and usage of fossil fuel. Conversely, renewable energy is environmentally friendly and increasing the use of renewable energy will improve the quality of the environment by contributing to a global reduction in greenhouse gas emissions.

- Renewable energy is sustainable as it has the capacity of being replenished by a natural technique at a cost that is equivalent to the energy being utilised.

- The collection, transformation and consumption of renewable energy regularly occur in an environmentally friendly manner. Unlike fossil fuels, renewable energy does not have damaging effects on the environment and can be made available to all society, regardless of status. Excess dependence on crude oil revenues has affected the growth of alternative energies in Nigeria. Energy diversification will promote energy security for the country as the international demands for Nigeria's crude oil are decreasing. From the prior statement on policy, the aims of the policy are: to promote sustainable energy sources for optimal energy fusion in a sustainable and ecologically friendly manner to diversify and to cushion the consequence of diversification from petroleum products as sources of energy. 
- There are many other anticipated advantages of renewable energy sources, such as: biofuel programme promoting the growth of the rural economy, education in rural-urban migration and energy supply security and a better ecosystem; maximizing carbon credit opportunities through the provision of direct and indirect employment in the power industry; freeing up more crude oil for export; boosting Federal and State Government tax revenues; providing returns on investment to farmers and other stakeholders in the industry; creating more opportunities for direct foreign investment in the Nigerian economy.

\subsection{The hurdles to legal sustainability of energy} substitution in the Nigerian electric power sector

Renewable energy has overwhelming benefits but is not devoid of side effects. Although renewable energy technologies emphasize environmentally friendly energy generation, energy production from some sources produces pollution. For example, biofuels may emit some pollution when combusted [36], so they still pose certain threats to the environment and human health.

In a bid to meet the demands for biofuels, the environment may be degenerated through deforestation, erosion, among other things, and this is contrary to one of the main aims of finding alternative sources of energy. Another problem is food security concern as a recent United Nations report indicates that attempting to develop crops for substitute energy use may put a massive strain on dwindling water resources as well as arable land for food. It could lead to a shortage of food during periods of droughts or famines. The expansion of agricultural land for the production of biofuel crops could also intensify the conflicts arising concerning land rights by the people, and the circumstances could force many countryside inhabitants to migrate to urban areas when they lose vital access to their natural resources such as water due to intensification in agricultural activities for bioenergy resources.

Another major hurdle to renewable energy development is technology. Apart from hydropower, solar and biofuel technologies, no other renewable energy technology has been developed in Nigeria. Most technologies have to be imported into Nigeria at high cost. In addition, the level of mechanisation in the agricultural sector is lower than that required for the improvement of farming practices to enhance quality and good yields.

Similarly, there is a problem of poor infrastructure, e.g., inadequate power supply, impassable road networks, poor water supply, all of which are critical for production, processing and distribution of both agricultural products and other materials related to the renewable energy programme.
Low public awareness of renewable energy sources and technologies in Nigeria as a viable energy source, and its economic and environmental advantages, has also to be addressed. Nigerians are not well informed about pressurising the Federal Government to develop renewable energy resources and technologies for commercialisation in the domestic energy market in Africa.

Generally, lack of cost-reflective charges, persistent interference by the Federal Government in private-led investments in the energy industry predominantly on issues of the tariffs and transmission problems are hurdles to investments in renewable energy. There is a need to deregulate the energy sector to encourage investors.

Unpredictable weather condition can have an adverse effect on energy supply. As renewable energy often depends on a variety of weather conditions, this may influence negatively the consistency of energy supply. For instance, hydro generators need sufficient rain to fill dams for their supply of flowing water, while wind turbines will need wind to generate power. Similarly, solar panels need clear skies and sunshine to generate electricity. It can also be challenging to produce the amount of power from renewables that are as large as conventional fossil fuel generators in Nigeria.

\subsection{The effects of the new energy policy on the petroleum sector in Nigeria}

Nigeria relies heavily on crude oil revenue and it provides over $90 \%$ of the country's foreign exchange earnings [37]. This has previously been the glory of the petroleum sector in Nigeria, while the new energy policy underscores the need to reduce over-dependency on crude oil as an energy source. The alternative sources of energy being promoted by the new energy policy have numerous benefits over fossil fuel. The policy also came at the right time when the United States, as one of Nigeria's biggest customers on petroleum products, redirected its energy policy to embrace a drastic reduction of crude oil consumption to reduce its overdependency on oil. This is a wake-up call for all stakeholders in the Nigerian upstream petroleum sector to implement the new energy policy on renewable energy for the sustainability of the oil and gas industry. The implications of the new energy policy are as follows.

First, the new energy policy will lead to a reduction in the demand for Nigeria's crude oil, while crude oil and its allied products are the live wire of Nigeria's economy. This is by no means an excellent signal to the Federal Government of Nigeria to diversify its economy to other viable sectors.

The second implication is that it will lead to an infusion of funds and modern technologies in the agricultural sector to the neglect of the petroleum sector and other revenue yielding sectors as the benefits of 
renewable energy outweigh those of fossil fuel, especially biofuel which is at the centre stage of the new energy policy and is much interwoven with the agricultural sector. Policymakers are to give priority to the agricultural sector over the petroleum sector in terms of funding and to make available the required funds for significant research on renewable energy and to provide the needed technological support for the sector [38].

Third, this may stimulate further decline in the crude oil price and its allied products in the sector because of a fall in demand. This could bring about an enormous slump in the petroleum sector.

Another consequence is that there would be a total remodelling of the automotive plants for $100 \%$ biofuel usage. This would mean a complete shift from fossil fuel to renewable energy, thereby rendering petroleum products dispensable globally.

Also, it may occasion retrenchment and down-sizing in the petroleum sector as one of the consequences of the economic downturn is the reduction of overheads and the number of employees in the sector by cutting costs. It is the author's view that retrenchment and downsizing may be inevitable in the sector due to low demand for petroleum products and decline in oil price.

In addition, the decline in the petroleum product price in the sector resulting from the implementation of the new energy policy could make crude oil and its allied products less attractive, thereby reducing the Niger Delta agitation for resource control and it may discourage pipeline vandalism among other oil-related crimes in the sector. Therefore, the Nigerian petroleum sector would experience relative peace, having the lives, properties and other oil assets of the multi-national oil and gas companies in the sector better safeguarded.

\subsection{Comparison of legal framework on renewable energy} Several countries have enacted legal frameworks on the growth and development of renewable energy, and some have provided incentives for the utilisation of renewable energy. For instance, the German Federal Building Code requires local authorities to designate an area for wind project developments. Similarly, the German Renewable Source Act 2001 made provision for the German wind market offering high feed-in-tariff for each kilowatt of power produced and providing priority grid access for renewable energy. It was initiated in 2001 and further confirmed in 2008 to encourage renewable energy utilisation in the country [39].

China's Renewable Energy Act 2006 provides the development, utilisation of renewable energy to guarantee energy security and preserve the environment, with a decentralized renewable energy structure. The Renewable Energy Plan 2005-2010 in Spain stipulates the development of renewable energy through technology to reduce dependency on the import of fossil fuel, to reduce emissions and to promote sustainability of energy. In 2009, the Indian Ministry for New and Renewable Energy guaranteed an incentive tariff for eligible renewable energy projects for ten years, with increasing tax on every metric ton of coal produced or imported to India to encourage the usage of clean energy and to discourage fossil fuel utilisation. A Green Bank and Indian Renewable Energy Development Agency were established to encourage the use of clean energy in the country, whereas Nigeria is yet to establish a Green Energy Bank. However, various renewable energy centres have been established in some Federal Universities across the country as renewable energy research hubs though some have not been efficient because of a lack of funds and of genuine commitment by the Federal Government to the power sector.

Denmark has generated over $40 \%$ of its energy consumption from wind energy while Morocco has the Ouarzazate plant to generate electricity for its citizens. In Venezuela and Columbia, the reasons for their adoption of renewable energy are to curtail attacks on their oil and electricity infrastructure and to guarantee energy security. In Kenya, renewable energy is made a national development priority. However, no similar policy exists in Nigeria. Although the current National Energy policy suggests the use of renewable energy sources it fails to make it a national concern to reduce the emission of carbon dioxide and to eliminate electricity blackouts and unreliable supply of electricity to consumers in the country [40]. It also fails to make provision for sanctions on practices such as non-metering of consumers and estimated billings by the electricity distribution companies [41].

In Nigeria, efforts to diversify from fossil fuel to renewable energy have not been successful because of the absence of a coherent, stringent legal framework on renewable energy and the lack of sincere commitment on the part of the Federal Government to overhaul the sector. Therefore, there is the need to learn from the range of legal frameworks and policy measures adopted by selected countries in developing and promoting renewable energy sources for stable electricity generation and transmission in Nigeria.

\section{Methodology}

This study aims to implement the new energy policy that has been embraced by several countries in the world to promote energy security and sufficiency. The Federal Government of Nigeria must depart from the use of fossil fuel and embrace alternative sources such as renewable energy resources to reduce greenhouse gas emission. Similarly, the society and natural environment have suffered dramatically because of environmental 
pollution and degradation resulting from the incidence of oil exploration activities in the Niger Delta Areas.

To attain this creditable aim, the library-based doctrinal legal research method is explored and validated by appropriate legal analysis, including references from internet sources, detailed evaluation of academic literature, appraisal of case studies and the analysis of substantial judicial and statutory provisions with comparative analysis of the legal framework for promoting renewable energy in China, Spain, Germany and India etc. The study adopts secondary sources, such as journals, textbooks and primary sources, such as case law with unstructured interviews with some energy consumers and regulatory bodies in the sector to gain useful insights and to use the lessons learnt in the selected case study countries to enact a regulatory policy or legal framework on renewable energy to ensure energy sufficiency and security.

\section{Recommendations}

In view of the findings in this research work, several recommendations are proposed as follows.

- There is a need for a legal regime that is favourable to development and sustainability, and the enactment of the new energy policy should be prompt. The Federal Government of Nigeria should be dedicated to the new energy policy to help mitigate the effect of the policy on the petroleum sector. As Nigeria depends heavily on crude oil for foreign exchange earnings, there is a need for more sources of revenue to the Federal Government via renewable energy.

- There is a need for continuous education of Nigerians on the new energy policy and a large scale marketing campaign to gain full acceptance of the energy policy. Fossil fuel energy is detrimental to the environment while renewable energy sources are ecologically friendly, sustainable and can boost electricity supply.

- The government should incorporate renewable energy into the country's energy system by making the utilisation of renewable energy an issue of national importance. There is a need for political will and absolute commitment of the government to the sustainability of renewable energy systems.

- There is a need to introduce renewable energy markets. Profit-oriented renewable energy in Nigeria requires the formation of energy markets for the rural energy consumers. To develop such a commercial market, it is necessary to strengthen investments in renewable energy development in the country, by enhancing services and training for the use of renewable energy technologies. Rural area energy consumers should be offered satisfactory repair and precautionary preservation of facilities locally.

- There is also a need for education of consumers on the necessary operational skills and techniques to help energy consumers set their everyday energy use efficiently to eliminate the need for copious energy storage facilities for renewable energy systems.

- Strong guidelines and standards are required for lawmakers on the best methods to adopt for the enactment of a legal framework and formulation of stringent policies on renewable energy use and developments with a clear understanding of the effects and the benefits of renewable energy utilisation in attaining energy security, efficiency and sustainability in Nigeria. Therefore, it is necessary to have a model legal framework on renewable energy as proposed by this study.

\section{Conclusions}

The paper provides a synopsis of the policy framework, legislative and regulatory measures that need to be taken to promote energy efficiency in Nigeria. The study highlights the significance of renewable energy to guarantee sustainable electricity with emphasis on a legal and policy framework that needs to be enacted to promote energy sufficiency and security through renewable energy. Considering the unreliable electricity supply in Nigeria and the limited power supply in the countryside, the need for energy source substitution is urgent.

The various significant gaps in the existing legal framework and policies on renewable energy have been highlighted. The justification for a new legal framework on renewable energy use, development and sustainability in the country has been further emphasised. From the preceding, it is clear that the world has fundamentally adopted a new energy policy which encourages a fundamental and drastic departure from fossil fuel to renewable energy, so Nigeria must also adopt such a policy and not be taken aback by the global energy scheme.

The new energy policy could negatively impact the Nigerian petroleum sector if Nigeria fails to diversify its economy to agriculture or other extractive resources. The essential question to ask is what is next after Nigeria implements the new energy policy like other countries in the world. There is the need for swift passage of the Petroleum Industry Governance Bill 2017 by the current 9th National Assembly to facilitate the implementation of the policy. However, there is little or no awareness in the public about the new energy programme. This may constitute a hindrance to the implementation of the new energy policy if not addressed speedily. The Federal Government must harness renewable energy sources and attract foreign investors by harmonizing all existing legal framework and energy 
policies. It needs to strengthen existing natural resource governance and reform the various regulatory institutions in the sector to make enforcement of renewable energy policy a national priority for the benefit of all Nigerians.

\section{Abbreviations}

PHCN: Power Holding Company of Nigeria; NEPA: National Electric Power Authority; GHGs: Greenhouse gases; EPSR: Electric Power Sector Reform Act of 2005; NERC: Nigerian Electricity Regulatory Commission; PIGB: Petroleum Industry Governance Bill, 2017

\section{Acknowledgements}

The financial support by Covenant University, Ota, Nigeria is gratefully acknowledged.

\section{Disclosure statement}

The authors declare no conflict of interest whatsoever.

\section{Author's contributions}

This author is sole responsible for this work. The author made all the contributions. The author(s) read and approved the final manuscript.

\section{Funding}

The financial support by Covenant University, Ota, Nigeria is gratefully acknowledged.

\section{Availability of data and materials}

Not Applicable.

\section{Ethics approval and consent to participate}

Not Applicable.

\section{Consent for publication}

Consent of the author for publication obtained.

\section{Competing interests}

No competing interest whatsoever.

Received: 11 April 2020 Accepted: 3 November 2020

Published online: 01 December 2020

\section{References}

1. Oniemola P., and Sanusi, G., (2007), The Nigerian Bio-Fuel Policy and Incentives, a Need to Follow the Brazilian Pathway, available at www.igee. org/en/publication/newsletter (accessed 18 Aug 2019).

2. Olujobi, O. J., Oyewunmi, O. A., \& Oyewunmi, A. E. (2018). Oil spillage in Nigeria's upstream petroleum sector: Beyond the legal frameworks. Int $J$ Energy Econ Policy, 8(1), 220-226.

3. Renewable Energy Policy of Nigeria 2006

4. Aderoju O.M., Dias, G..A., \& Echakraoui, Z., (2017), Assessment of renewable energy sources and municipal solid waste for sustainable power generation in Nigeria, world multidisciplinary earth sciences symposium, IOP conference, Series: Earth and Environmental Science, 7.

5. Oke, Y. (2013). Nigerian electricity law and regulation, law lords publication 322 Oke, Y., (2013), Nigerian electricity law and regulation, Law Lords Publication, (p. 322).

6. Olujobi, O. J. \& Oyewunmi, O. A. (2017). Annulment of Oil Licences in Nigeria's Upstream Petroleum Sector: A Legal Critique of the Costs and Benefits. Int J Energy Econ Policy, 7(3), 364-369.

7. Smith, R.,(2018), Three Countries are Leading the Renewable Energy Revolution, available at World Economic Forum, https://www.weforum.org/ agenda/2018/02/countries-behind-global-renewable-energy-growth/ (accessed 10 Apr 2020).

8. Obama, (2004), The All-of-The-Above Energy Strategy as a Path to Sustainable Economic Growth, available at https://obamawhitehouse. archives.gov/sites/default/files/docs/aota_report_updated_july_2014.pdf

9. Lukman, R., (2009), US New Energy Policy a Threat to Nigeria's Oil and Gas Sector, a speech delivered at a roundtable meeting between US delegation and the Nigerian government officials, in Abuja on May 24,
2009, by the Honourable Minister of Petroleum, Rilwan Lukman, through his representative, the Special Adviser to the President on Petroleum Matters - Emmanuel Egbogah, available online at www. onlinenigeria.com, (accessed 2 Sept 2019).

10. Olujobi, O. J. (2020). Analysis of the Legal Framework Governing Gas Flaring in Nigeria's Upstream Petroleum Sector and the Need for Overhauling. MDPI J Soc Sci, 9, 132

11. Fig. 1, Map of Nigeria Showing Geographic Allotment of Nigeria's Compendium of Energy Sources, [Dantata Solar Limited Nigeria's: Solar Resources and Potentials - Dantata Solar, Ltd https:/www.google.com/ imgres?imgurl=https\%3A\%2F\%2Fwww.dantatasolar.com\%2f.cm4all\%2 fuproc.php\%2fo\%2f.solargis-nigeria-ghi-solar-resource-map-en.png\%2 fpicture-1200\%3f \%3d1636acce920\&imgrefurl=https\%3a\%2f\%2fwww. dantatasolar.com\%2fwhy-solar-power\%2fnigeria-s-solar-resources $\% 2$ fmobile\%2f\&tbnid=fy8p0ccutaoj6m\&vet=10cakqxiaoawoxchmi2mj9jovg6 wivaaaab0aaaaaeai..i\&docid=k-tum9ybyvjbom $\& \mathrm{w}=850 \& \mathrm{~h}=750 \& \mathrm{itg}=1 \& \mathrm{q}=$ excellent\%20map\%20of\%20nigeria\%20exhibiting\%20renewable\%2 0energy\&ved=0cakqxiaoawoxchmi2mj9jovg6wivaaaaab0aaaaaeai]

12. Omorogbe, Y., (2016), Promoting sustainable development through the use of renewable energy: The role of the law, in beyond the carbon economy energy law in transition, D. N Zillman, C., Redgwell, Y.O., Omorogbe, L., Barrera-Hernandez, Oxford University press, 39-59. Available at:https://www. researchgate.net/publication/290836523_Promoting_Sustainable_ Development_through_the_Use_of_Renewable_Energy_The_Role_of_the_ Law (accessed 20 Oct 2020).

13. Ajomo, M. A. (2001). The legal framework of the petroleum industry, being a paper presented at the Centre for Petroleum Environment and Development Studies Workshop on essentials of oil and gas, Lagos, Nigeria.

14. Oke, Y. (2016). Essays on Nigerian electricity law, Princeton and associate publishing co. Itd, Lagos, (pp. 93-113).

15. Mallon, K. (2006). Renewable energy policy and politics, a handbook for decision -making. London: Earthscan.

16. Oyedepo, S. O. (2012). Energy and sustainable development in Nigeria: The way forward. Energy Sustainability and Society, 2(15), 1-17.

17. Olujobi, O. J. (2020). Recouping Proceeds of Corruption: Are There Any Need to Reverse Extant Trends by Enacting Civil Forfeiture Legal Regime in Nigeria? J Money Laundering Control (In Press).

18. Olujobi, O. J., \& Olusola-Olujobi, T. (2020). Comparative Appraisals of Legal and Institutional Frameworks Governing Gas Flaring in Nigeria's Upstream Petroleum Sector: How satisfactory? Environmental Quality Management, 1-14

19. Olujobi, O. J., Olujobi, O. M., \& Ufua, D. E. (2020). The Legal Regime on Renewable Energy As Alternative Sources of Energy in Nigeria's Power Sector: The Impacts and the Potentials. Acad Strategic Management J, 19(3), 1-16.

20. Olujobi, O. J. (2020). Renegotiation and Stabilisation Clauses in Nigeria's Upstream Petroleum Industry's Contracts: The Issues and the Options. Int $J$ Innovation Creativity Change, 14(2), 1331-1350.

21. Olujobi, O. J., \& Olusola-Olujobi, T. (2019). the Appraisal of Legal Framework Regulating Gas Flaring in Nigeria's Upstream Petroleum Sector: How Efficient? Int J Civil Engineering Technol, 10(5), 256-272.

22. Olujobi, O. J., \& Olujobi, O. M. (2020). Theories of corruption: Public choiceextractive theory as alternative for combating corruption in Nigeria's upstream petroleum sector. Int I EnvironSustainability Green Technologies (IJEST), $11(2), 12$.

23. Oyewunmi, O. A., \& Olujobi, O. J. (2016). Transparency in Nigeria's oil and gas industry: Is policy re-engineering the way out? Int J Energy Econ Policy, 5(4), 630-636

24. Ganda, Y.M., Danshehu B. G and. Zarma, I. H., (2013), The Role of Renewable Energy in Improving Energy Access to Rural Areas in Nigeria, Being a Paper Submitted for World Energy Council DAEGU 2013 Congress From 13-17. Available at: file:/c:/users/hp/downloads/ theroleofrenewableenergyinimprovingenergyaccesstoruralareasinnigeria.pdf (accessed 9 Apr 2020)

25. Ben-Iwo, J. (2016). Biomass resources and biofuels potential for the production of transportation fuels in Nigeria. Renew Sust Energ Rev, 63, 172-192.

26. Africa first ethanol refinery was flagged off in Ekiti State in 2009 and another one in Ondo State same year. Available at: www.bioenergy site. com (accessed 27 July 2019).

27. Oyedepo, S. O., \& Babalola, O. P. (2018). Towards a sustainable electricity supply in Nigeria: The role of decentralised renewable energy system. Eur J Sustainable Dev Res, 2(2), xx. 
28. Akinyetun, T. S. (2016). Nigeria and oil production: Lessons for future. Int $J$ Multidisciplinary Res Dev, 3(5), 19-24.

29. Olujobi, O.J., (2017), Legal framework for combating corruption in Nigeria The upstream petroleum sector in perspective, journal of advanced research in law and economics, Vol. Viii, Summer, 3(25): 956-997.

30. Olujobi, O. J., Olujobi, O. M., \& Ufua, D. E. (2020). A Critical Appraisal of Deregulation of the Downstream Sector of the Nigerian Petroleum Industry. J Management, 11(6), 252-268.

31. Yusuf, A. O., (2006), The Nigerian Fuel Ethanol Industry, Presentation at the International Conference on Bio-Fuel Markets in Africa held in Cape Town, South Africa on November 30 to December 1, 2006 Available at: www.greenpowerconferences.com/biofuelsmarket/documents, (accessed July 2019).

32. Piters, B., How Sustainable are Biofuels? Between Common Curiosity and Confronting-Interests". Available: at: http://knowledge.cta.int/en/dossiers/s-tissue-in perspective/biofuels/articles/how-sustainable-are-biofuels-betweencommon-curiorsity-and-confronting-interests (accessed 10 Apr 2020).

33. Oluseyi, O. A., Fagbenle, R. O., et al. (2014). Wind energy study and energy cost of wind electricity generation in Nigeria: Past and recent results and a case study for south-west. Nigeria, Energies, 7, 8512.

34. Table 1 Source: Oluoti, Megwai, Pettersson and Richards, 2014].

35. Sagay, I. E. (2005). The Niger Delta and the Case for Resource Control in Nigeria Being a Public Lecture Delivered in Honour of Honourable Justice Adolphus Karibi -Whyte at the University of Ife on Friday, May 8.2005.

36. Steenblik, R. (2005). Liberalisation of trade in Renewable Energy Products and Associated Goods: Charcoal, Solar Photovoltaic Systems, and Wind Pumps and Turbines, OECD Trade and Environment Working Paper.

37. Monday, T. U., \& Salihu, M. (2017). Crude Oil and the Politics of Nigerian Foreign Policy: Issues and Explanations. Res Human Soc Sci, 7, 38.

38. The National Energy Policy, 2003; The foreword by Rilwanu Lukman, Presidential Adviser on Petroleum and Energy (former Minster of Petroleum), $v$.

39. Fulton, M., (2012), German Feed-in Tariff: Recent Policy Changes, Available at https:/www.db.com/cr/en/docs/german_fit_update_2012.pdf (accessed 10 Apr 2020)

40. National Renewable Energy and Energy Efficiency Policy, (2015), available at http://www.power.gov.ng/download/nreee\%20policy\%202015-\%20fec\%2 Oapproved\%20copy.pdf (accessed 10 Apr 2020), 38.

41. National Energy Policy 2018.

42. Fig. 3 Renewable Energy Sources, My Energy Greek, available at: http:// myenergygeek.com/comparing-the-3-most-promising-renewable-energysources/, accessed 3 Aug 2020]

\section{Submit your manuscript to a SpringerOpen ${ }^{\circ}$ journal and benefit from:}

- Convenient online submission

- Rigorous peer review

- Open access: articles freely available online

High visibility within the field

- Retaining the copyright to your article

Submit your next manuscript at $\boldsymbol{\nabla}$ springeropen.com 